\title{
The Role of the Department Chair: A Replication and Extension*
}

\author{
ROY E.L. WATSON $†$
}

\begin{abstract}
This article reports the findings of a survey of faculty opinion which both replicated and extended an earlier study of the perception of the chairperson's role at one university. Broad agreement now exists in the definition of this role. Social Scientists no longer hold views which conflict with those of their Natural Science and Humanist colleagues. This strong consensus is best explained by the shared experience of being administered by a bureaucracy established in response to the demands of the 1960's for reform of university administration.
\end{abstract}

\section{RÉSUMÉ}

Cet article porte sur les résultats d'un sondage sur la perception qu'ont les professeurs du rôle du directeur de département dans une université. L'unanimité est maintenant faite sur la définition de ce rôle. De fait, les professeurs des sciences sociales ont même abandonné leurs points de vue qui allaient à l' encontre de ceux de leurs collègues des sciences naturelles et des humanités. Cette unanimité découle de leur expérience commune de soumission à une bureaucratie qui a été établie à la suite des demandes de réforme de l'administration universitaire formulées dans les années 60.

By the late 1960s, the reform of university administration which had been stimulated by the Duff/Berdahl Report (1966) was leading to a decentralization of decision-making and concomitant increase in the influence of faculty in formulating policy. Together with the continuing growth of universities and their budgets, this had greatly increased both the scope and the importance of departmental administration. In spite of this development, the academic literature on university governance has emphasized the higher levels of administration and

* This research was supported in part by a grant from the Social Sciences and Humanities Research of Council of Canada administered by The University of Victoria. I would like to acknowledge the assistance of Peter DeMeo in data collection and of Eugene Deen in programming data analysis.

$\dagger$ Associate Professor, University of Victoria 
the offices of President and Deans to the neglect of research on departments and the key role of the chairperson. ${ }^{1}$ There is some empirical evidence, at least for American universities, that the department chair is perceived to have less power than faculty in general (Gross, 1968:537; Gross and Grambsch, 1974:120). But most of this literature can be described as theoretical or normative in its thrust (Peltason in Tucker, 1981:xi; Murray, 1964:227; Morris, 1981:7). It describes what the role of the chair ought to be, commonly identifying the exercise of academic leadership as essential (Ahmann, 1972:188; Dilley, 1972:29; McHenry, 1977:190; Whitson, 1982:163). Not surprisingly, the role is frequently described as "... difficult and ambiguous" (Brann and Emmet, 1972:5) and ... "beset by contradictions" (Tucker, 1981:23; cf. Booth, 1982:15).

In an earlier article (Watson, 1979), we speculated that at least a part of the often bitter controversy about university governance, which had erupted on many campuses during the sixties, had focussed on departments and could be traced to values inherent in different academic disciplines. Based on an analysis of survey data collected at one Canadian university, it described a sharp division of opinion among faculty with respect to how their departments should be administered. Some looked for a 'Head' "... who would remain in office for a relatively long period during which ... he would be reasonably free to give direction to his department." Others felt that the key role was that of a representative to other levels of administration, committees and the like. This person should be known as 'Chairman' and "... if proved satisfactory might be reappointed but who, during his term of office, would operate within a democratic framework." Yet a third group identified the role of coordinator as most important, someone to facilitate the work of colleagues and relieve them of administrative chores. This group also wanted a 'Chairman' and, while approving of possible reappointment, did so less strongly.

These different perceptions of the desired role of a departmental chair were found to reflect the academic disciplines of the respondents. Both Natural Scientists and Humanists at the university surveyed chose the role of leader as most important, followed by coordinator and representative. Among Social Scientists, however, a clear majority selected the coordinator role, followed by representative, while only a small minority looked on the academic leadership role positively. These contrasting perceptions of the role would not have had much significance had Social Scientists been administered in departments organized in terms of their own values. On most campuses, however, Social Scientists were predominantly recent arrivals who had been recruited to departments, newly established or greatly expanded, in response to the growing popularity of these disciplines after the war. The departments they had joined were modelled on those of the older disciplines. This model incorporated a leadership role which was neither desired by nor acceptable to most Social Scientists. In their efforts to change it, they were prominent in the controversies which erupted on many campuses.

By the 1980s, universities were again tranquil centers of learning and research and the earlier disputes, a distant memory. Universities had responded to the 
earlier period of turmoil by introducing many changes affecting all levels of university administration, changes which satisfied many of the demands for a more participatory mode of decision-making. But, perhaps, the major legacy was in an emphasis upon proper procedures being followed at all levels. This had contributed, in no small measure, to a markedly increased bureaucratization of the administrative process (cf. Smelser and Content, 1980:170; Gross and Grambsch, 1974:6). As a direct result of this, most decisions which impinged on faculty and their careers, by the early 1970s, were made under explicit procedures which defined who should be involved in the process, when they should take place and what criteria should be used, along with many other details.

In a seminal paper, R.K. Merton (1949:156) described how

\begin{abstract}
"... through the organizational devices of promotion by seniority, pension, incremental salaries, etc., all of which are designed to provide incentives for disciplined action and conformity to official regulations, [the] official is tacitly expected to and largely does adapt his thoughts, feelings, and actions to the pursuit of [his] career ..."
\end{abstract}

While Merton was referring to governmental bureaucracies and their staffs, could not the structuring of the careers of academics, albeit by a contrasting set of rules more appropriate to universities, produce a corresponding effect upon their thoughts, feelings and actions? Had the experience of the university bureaucracy and its procedures, developed in response to the previous disputes, overcome the divisive influence which was earlier ascribed to disciplinary backgrounds?

An alternative explanation of the tranquility of the contemporary campus, however, is possible. Beginning in the 1970 s, faculty were affected, not only by the administrative changes being made within the universities, but by a major external change - the slowing and, then, reversal of the rapid growth which had been experienced since the early fifties (cf. Tucker, 1981:86-7). This transformed the employment situation in most disciplines from a sellers to a buyers market (cf. Smelser and Content, 1980). Those fortunate in having secured a university appointment were increasingly aware that, with few alternative opportunities opening, their careers were critically dependent upon satisfying the productivity and other norms of their institutions. Under these circumstances, little time and energy may have been left for campus issues, whatever the private thoughts and feelings of faculty may have been. Others may simply have avoided any action which might jeopardize their careers. In either case, the tranquility of the campus could be attributed to the impact of external changes rather than to a change in the values held by individuals. The research to be reported aimed to discover which of these explanations accounts more satisfactorily for the present absence of controversy, at least on one university campus.

\title{
METHOD
}

In a partial replication of the previous survey, full-time members of the Faculty of Arts and Science at the University of Victoria were asked to complete a confidential questionnaire during the Spring Term of 1984. As in the earlier study, 
five roles of "a department's chief administrative officer" were identified and the respondents were asked to rank these in terms of their importance. To avoid sexist language, the descriptions of the roles were slightly modified from the earlier survey to read as follows:

"Intellectual leader - to define the academic goals of the department and devise programmes to achieve these.

Co-ordinator/Administrator - to coordinate the work of members of the department and to facilitate their productivity by relieving them of routine administrative duties.

Representative - to represent the department to other officers of the university, in committees, etc.

Resource Mobilizer - to know about and assist colleagues in obtaining the resources they require, particularly from sources external to the university.

Personnel Administrator - to assess the individual members of the department, their contributions and potentialities."

In addition to this and other salient questions from the earlier survey, the questionnaire extended the investigation of departmental administration by incorporating an item which identified twenty specific administrative areas. ${ }^{2}$ Five of these were described as involving "... the power to decide changes in existing policies or practices" and the remaining fifteen concerned administrative decisions to implement existing policies. With respect to each area, respondents were asked whether individual faculty, an elected committee, the chairperson alone or consulting at his choice, or a meeting of the full department should have the power to decide insofar as this power resides in the department. In all, 227 usable questionnaires were returned which, allowing for faculty on leave or ill, represents a participation rate of over 80 percent.

\section{FINDINGS}

The rank ordering of the importance attached to each of the five roles is given in Table $\mathrm{I}^{3}$ together with the comparative percentages received in the previous survey.

As is apparent, a higher percentage (43.5\%) now assign first importance to the role of Coordinator, while Leader has dropped sharply to 20.9 percent and is closely followed by Representative at 19.4 percent. The weighted mean scores may provide a better measure, however, and show that Representative ranked second in importance to Coordinator, with Leader much lower. The roles of Resource Mobilizer and Personnel Administrator ranked still lower and will not be considered further.

While the presentation of the data in Table I conveys an impression of some continuing disagreement in the way in which the department administrator is viewed, other responses suggest a high level of consensus. So, for example, while more of those who give first priority to leadership favour the title 'Head', 80.7 percent of this group now prefer 'Chairperson'. Those selecting the Coordinator (87.6\%) and Representative $(88.5 \%)$ roles approve the latter title still more 
Weighted 
Table II. Selection of Most Important Role of the Department Administrator by Disciplinary Area, 1984 and 1970

\begin{tabular}{|c|c|c|c|c|c|c|c|c|c|c|c|}
\hline & \multicolumn{9}{|c|}{ Most Important Role } & \multirow{2}{*}{\multicolumn{2}{|c|}{ All }} \\
\hline & \multicolumn{3}{|c|}{ Leader } & \multicolumn{3}{|c|}{ Coordinator } & \multicolumn{3}{|c|}{ Representative } & & \\
\hline & \multicolumn{2}{|c|}{1984} & \multirow{2}{*}{$\frac{1970}{8}$} & \multicolumn{2}{|c|}{1984} & \multirow{2}{*}{$\frac{1970}{8}$} & \multicolumn{2}{|c|}{1984} & \multirow{2}{*}{$\frac{1970}{8}$} & & \\
\hline & $\mathrm{n}$ & 8 & & $\mathrm{n}$ & $q$ & & $\mathrm{n}$ & 8 & & $\mathrm{n}$ & 8 \\
\hline $\begin{array}{l}\text { Social } \\
\text { science }\end{array}$ & 13 & 19.4 & 6.3 & 36 & 53.7 & 58.3 & 18 & 26.9 & 35.4 & 67 & 100 \\
\hline $\begin{array}{l}\text { Natural } \\
\text { science }\end{array}$ & 24 & 32.0 & 44.3 & 35 & 46.7 & 39.3 & 16 & 21.3 & 16.4 & 75 & 100 \\
\hline Humanities & $\underline{21}$ & 23.1 & 43.2 & $\underline{50}$ & 54.9 & 36.8 & $\underline{20}$ & 22.0 & 20.0 & 91 & 100 \\
\hline & 58 & 24.9 & 34.8 & 121 & 51.9 & 42.6 & 54 & 23.3 & 22.5 & 233 & \\
\hline
\end{tabular}

Social Science vs. Natural Science $x^{2}=2.97$ 2df N.S. $x^{2}=20.0124 p<.0001$ Social Science vs. Humanities $x^{2}=1.192$ df N.S. $\quad x^{2}=20.5582 p<.0001$ Natural Scienoe vs. Humanities $\mathrm{x}^{2}=1.76$ 2df N.S. $\quad \mathrm{x}^{2}=.3319$ N.S.

strongly but the variation does not reach the level of statistical significance. Similarly with respect to the term of office of incumbents. While 86.2 percent of all respondents approve of a fixed term of three or four years with possible reappointment, those giving priority to leadership are somewhat less likely $(6.8 \%)$ to approve of the options - no reappointment and shorter terms rotated - which would ensure regular change in the incumbents. Among those selecting Coordinator, 16.8 percent chose these options as did 9.5 percent of the Representative group but, again, the variations do not reach significance. Finally, asked whether "Deans, Heads/Chairperson ... should be left free to [administer] without ... a lot of democratic checks," those selecting Representative (33.3\%) were as likely as the Leader group (32.1\%) to agree - as against 18.2 percent of the Coordinator group - but the differences are not significant. In summary, some who believe that the role of a department administrator is preeminently to provide academic leadership still appear to hanker for a 'Head' who will hold office sufficiently long to make an impression and will enjoy sufficient freedom of action to be able to do so. But they appear to be a dwindling company. The great majority now approve of 'Chairs' who operate within a broadly participatory form of administration and see coordination and representation as the major roles. 
As in the earlier study, respondents were grouped into Social Science, Natural Science and Humanities ${ }^{4}$ and their selections of the most important role tabulated. The results, with corresponding percentages from the earlier survey are given in Table II. In marked contrast to that study, the selections made by Social Scientists no longer differ significantly from those of either their Natural Science or Humanist colleagues. Examination of the data to discover whether the selection of the most important role was influenced by such other individual attributes as age, sex, academic rank, length of time at the university, total teaching experience, nationality and where first and highest degrees had been obtained also failed to reveal a statistically significant relationship as did the size of department. It would appear, therefore, that while there continues to be some disagreement as to the most important role performed by a department chair, those disagreeing are fewer in number and scattered across the faculty rather than, as in the past, identified with particular subject areas.

In addition to characterizing the expectations held of the department chair in terms of its major role, our data identify a number of the specific areas of responsibility given to this office. As is apparent in Table III, faculty generally believe that the power to amend academic policies pertaining to overall goals, the degree programme, student admission and academic standards should rest with the full department, not the Chair. Only with respect to formulating the annual budget is the chair's authority clear. When the decisions involve implementing existing policy, the Chair is assigned a major responsibility for what might best be described as 'routine' administration; such matters as course scheduling, allocation of space and other facilities, assigning course load and administering the department budget. The crucial decisions relating to graduate students - their recruitment/selection and the assignment of graduate assistantships - are perceived as belonging to an elected committee. This was generally true also of decisions with respect to faculty careers - tenure, promotion and reappointment - though respondents are divided nearly equally between those favoring an elected committee and the full department for recruiting new faculty. Only with respect to faculty salary decisions, however, does the Chair retain the major responsibility. One area of decision-making, that of research funding, is perceived by most to be an individual responsibility. Finally, there are two areas - the evaluation of research and the determination of the department's course offering - in which there is no clear majority favoring any one option.

\section{DISCUSSION}

The present study has 'explored faculty members' perceptions of the department chair with respect to both the importance they assign to general roles and the means they favour for deciding specific matters. The consistency of responses to these questionnaire items is impressive. With the single exception of salary matters, all decisions relating to personnel - appointment, dismissal, the award of tenure or 
I The power to decide upon changes in existing policies/practices

Locus of Decision

\begin{tabular}{|c|c|c|c|c|c|c|c|c|c|c|}
\hline \multirow[b]{3}{*}{ Administrative Area } & & \multirow{2}{*}{\multicolumn{2}{|c|}{ All }} \\
\hline & \multicolumn{2}{|c|}{$\begin{array}{l}\text { Individual } \\
\text { faculty }\end{array}$} & \multicolumn{2}{|c|}{$\begin{array}{c}\text { Elected } \\
\text { conmittee }\end{array}$} & \multicolumn{2}{|c|}{$\begin{array}{c}\text { Chairperson } \\
\text { with/without } \\
\text { advioe } \\
\end{array}$} & \multicolumn{2}{|c|}{$\begin{array}{c}\text { Full } \\
\text { department }\end{array}$} & & \\
\hline & $\mathrm{n}$ & 8 & $\mathrm{n}$ & 8 & $\mathrm{n}$ & 8 & $\mathrm{n}$ & 8 & $\mathrm{n}$ & 8 \\
\hline $\begin{array}{l}\text { Determine overall goals } \\
\text { Formulate budget } \\
\text { Academic program } \\
\text { Student admission } \\
\text { Academic standards }\end{array}$ & $\begin{array}{r}5 \\
- \\
1 \\
2 \\
14\end{array}$ & $\begin{array}{r}2.2 \\
- \\
.4 \\
.9 \\
6.2\end{array}$ & $\begin{array}{l}12 \\
58 \\
59 \\
70 \\
41\end{array}$ & $\begin{array}{r}5.3 \\
25.7 \\
26.1 \\
30.8 \\
18.2\end{array}$ & $\begin{array}{r}7 \\
145 \\
4 \\
10 \\
7\end{array}$ & $\begin{array}{r}3.1 \\
64.2 \\
1.8 \\
4.4 \\
3.1\end{array}$ & $\begin{array}{r}\frac{203}{23} \\
\frac{162}{145} \\
163 \\
\end{array}$ & $\begin{array}{l}89.4 \\
10.2 \\
71.7 \\
63.9 \\
72.5 \\
\end{array}$ & $\begin{array}{l}227 \\
226 \\
226 \\
227 \\
225\end{array}$ & $\begin{array}{l}100.0 \\
100.1 \\
100.0 \\
100.0 \\
100.0\end{array}$ \\
\hline \multicolumn{11}{|c|}{ II Administer existing policies } \\
\hline $\begin{array}{l}\text { Course scheduling } \\
\text { Course offering } \\
\text { Allocate facilities } \\
\text { Allocate other resources } \\
\text { Research funding } \\
\text { Departmental budget } \\
\text { Assign graduate assistants } \\
\text { Assign faculty work } \\
\text { Select graduate students } \\
\text { Recruit new faculty } \\
\text { Tenure } \\
\text { Pramotion } \\
\text { Salary } \\
\text { Non-reappointment } \\
\text { Evaluate research }\end{array}$ & $\begin{array}{r}16 \\
10 \\
1 \\
7 \\
163 \\
- \\
4 \\
3 \\
25 \\
1 \\
1 \\
- \\
- \\
1 \\
54\end{array}$ & $\begin{array}{r}7.1 \\
4.4 \\
.4 \\
3.1 \\
72.4 \\
\overline{1.8} \\
1.4 \\
11.1 \\
.4 \\
.4 \\
- \\
.4 \\
26.6\end{array}$ & $\begin{array}{r}33 \\
72 \\
47 \\
61 \\
33 \\
25 \\
147 \\
33 \\
180 \\
114 \\
171 \\
175 \\
66 \\
148 \\
98\end{array}$ & $\begin{array}{l}14.7 \\
31.9 \\
20.9 \\
27.4 \\
14.7 \\
11.0 \\
65.0 \\
14.9 \\
80.0 \\
50.4 \\
75.3 \\
77.4 \\
29.1 \\
65.8 \\
48.3\end{array}$ & $\begin{array}{r}\frac{161}{61} \\
\frac{151}{135} \\
\frac{135}{26} \\
\frac{199}{62} \\
153 \\
8 \\
2 \\
9 \\
10 \\
153 \\
21 \\
49\end{array}$ & $\begin{array}{r}71.6 \\
27.0 \\
67.1 \\
60.5 \\
11.6 \\
87.7 \\
27.4 \\
68.9 \\
3.6 \\
.9 \\
4.0 \\
4.4 \\
67.4 \\
9.3 \\
24.1\end{array}$ & $\begin{array}{r}15 \\
83 \\
26 \\
20 \\
1 \\
3 \\
13 \\
33 \\
12 \\
109 \\
46 \\
41 \\
8 \\
55 \\
2\end{array}$ & $\begin{array}{r}6.7 \\
36.7 \\
11.6 \\
9.0 \\
.4 \\
1.3 \\
5.8 \\
14.9 \\
5.3 \\
48.2 \\
20.3 \\
18.1 \\
3.5 \\
24.5 \\
1.0\end{array}$ & $\begin{array}{l}225 \\
226 \\
225 \\
223 \\
223 \\
227 \\
226 \\
222 \\
225 \\
226 \\
227 \\
226 \\
227 \\
225 \\
203\end{array}$ & $\begin{array}{l}100.1 \\
100.0 \\
100.0 \\
100.0 \\
100.1 \\
100.0 \\
100.0 \\
100.0 \\
100.0 \\
100.0 \\
100.0 \\
100.0 \\
100.0 \\
100.0 \\
100.0\end{array}$ \\
\hline
\end{tabular}


promotion - are assigned, most commonly, to an elected committee followed by the full department. Hardly anyone perceives the Chair to be appropriate to decide, a fact reflected in the low importance assigned to personnel administration as a general role. Similarly, those areas of decision-making which are crucial to the exercise of academic leadership - the setting of goals and objectives, the design of programmes and decisions in admission policy and academic standards - are assigned, not to the Chair, but to the full department or an elected committee. This confirms the relatively low importance now given to academic leadership as a general role. The role of the Chair as Coordinator/Administrator, which is most likely to be given first importance, is seen to consist mainly of decisions affecting things - with setting and, then, administering the budget, allocating offices and other facilities, assigning courses to instructors and arranging their schedules. Such decisions are not without important ramifications for individuals' performances and so, ultimately, the evaluations which may be reached by a committee of their peers. But an incumbent whose powers are so limited can scarcely be expected to exert the leadership which is so commonly urged upon the department chair in the literature.

The most striking finding of the present survey, however, is the growth in consensus which has occurred with respect to the position of Chair over the past fourteen years. Not only does a clear majority now exist with respect to most aspects of the role from its title to the specific powers of its incumbent, but the minority who disagree are scattered widely. No longer are different perceptions of the role associated with particular disciplines. The values, thoughts and feelings which are held are now very similar across the faculty.

It remains to be asked what has produced this consensus. Certainly, it cannot be attributed to respondents hiding their true opinions through fear of some consequence. Rather, it must be traced to the molding of thoughts and feelings which has been produced by the common experience of the bureaucracy of the contemporary university. Faculty have come to accept, indeed, to approve of the ways in which they are administered and, while there may continue to be individual complaints, there are no longer strong pressures for change as individuals strive to meet the criteria applied to them by that bureaucracy. This dramatic change in faculty opinion is another illustration of what Merton earlier identified as the power of bureaucratic structures to mold personality.

\section{FOOTNOTES}

1. For a comprehensive review of the research literature on departments, see David Booth, 1982.

2. These were drawn from 29 "Managerial tasks associated with the department chairperson position" listed in Whitson and Hubert, 1982:170-1.

3. Unfortunately, 54 or nearly one quarter of the respondents did not rank all five roles in the order of relative importance but interpreted the instruction to require an assessment of the importance of each role separately. This led to two or more roles being given the same rank. Where this was done, responses were coded to show that different roles received equal rank. This has resulted in the total of first choices exceeding the number of respondents. The distribution of choices, excluding the 54 cases, is given below in Table I(a). Similar calculations were made for all other statements in the text and in no case is a different conclusion indicated. 
Table I(a). The Importance of the Department Administrators' Roles

\begin{tabular}{|c|c|c|c|c|c|c|c|c|c|c|c|}
\hline \multirow{3}{*}{$\begin{array}{l}\text { Rank } \\
\text { assigned }\end{array}$} & \multicolumn{11}{|c|}{ Roles } \\
\hline & \multicolumn{2}{|c|}{ Leader } & \multicolumn{2}{|c|}{ Coordinator } & \multicolumn{2}{|c|}{$\begin{array}{c}\text { Repre- } \\
\text { sentative }\end{array}$} & \multicolumn{2}{|c|}{$\begin{array}{l}\text { Resource } \\
\text { mobilizer }\end{array}$} & \multicolumn{2}{|c|}{$\begin{array}{c}\text { Personnel } \\
\text { administrator }\end{array}$} & \multirow{2}{*}{$\begin{array}{l}\mathrm{A}] \mathrm{ll} \\
\mathrm{n}\end{array}$} \\
\hline & $\mathrm{n}$ & 8 & $\mathrm{n}$ & 8 & $\mathrm{n}$ & $\frac{8}{8}$ & $\mathrm{n}$ & 8 & $\mathrm{n}$ & 8 & \\
\hline First & 38 & 22.8 & 90 & 53.9 & 23 & 13.8 & 10 & 6.0 & 6 & 3.6 & 167 \\
\hline Second & 19 & 11.5 & 32 & 19.4 & 75 & 45.5 & 12 & 13.3 & 17 & 10.3 & 165 \\
\hline Third & 39 & 23.5 & 18 & 10.8 & 36 & 21.7 & 38 & 22.9 & 35 & 21.1 & 166 \\
\hline Fourth & 31 & 18.6 & 15 & 9.0 & 26 & 15.6 & 35 & 21.0 & 60 & 35.9 & 167 \\
\hline Fifth & 39 & 23.5 & 12 & 7.2 & 6 & 3.6 & 61 & 36.7 & 48 & 28.9 & 166 \\
\hline All & 166 & & 167 & & 166 & & 166 & & 166 & & \\
\hline No response & 7 & & 6 & & 7 & & 7 & & 7 & & \\
\hline $\begin{array}{l}\text { Weighted } \\
\text { mean rank }\end{array}$ & 3.1 & & 2.0 & & 2.5 & & 3.7 & & 3.8 & & \\
\hline
\end{tabular}


4. The three groups were composed of the following departments:

Social Sciences: Anthropology, Economics, Geography, Political Science, Psychology, Sociology.

Natural Sciences: Bacteriology and Biochemistry, Biology, Chemistry, Computing Science, Mathematics, Physics.

Humanities: Classics, English, French Language and Literature, German Language and Literature, Hispanic and Italian Studies, History, Linguistics, Philosophy, Slavonic and Oriental Studies.

While this grouping is arbitrary in some respects, it is necessary to protect the anonymity of respondents which might be lost if individual departments were reported.

\section{REFERENCES}

Ahmann, J.S. (1972). "The Emerging Role" in J. Brann and T.A. Emmett, eds., The Academic Department or Division Chairman: A Complex Role, pp. 186-197.

Booth, D.B. (1982). The Department Chair: Professional Development and Role Conflict, AAHEERIC Higher Education Research Report \#10, Washington, D.C., American Association for Higher Education.

Brann, J. \& Emmet, T.A., eds. (1972). The Academic Department or Division Chairman: A Complex Role, Detroit: Balamp Publishing.

Dilley, F.B. (1972). "The Department Chairman as Academic Planner" in James Brann and Thomas A. Emmet, eds., The Academic Department or Division Chairman: A Complex Role.

Duff, Sir James \& Berdahl, R.O. (1966). University Government in Canada, Toronto, University of Toronto Press.

Gross, E. (1968). "Universities as Organizations: A Research Approach," American Sociological Review 33(4):518-544.

Gross, E. \& Grambsch, P.V. (1974). Changes in University Organization, 1964-1971, New York, McGraw Hill Book Co.

McHenry, D.E. (1977). Academic Departments, San Francisco: Jossey-Bass Publishers.

Merton, R.K. (1949). "Bureaucratic Structure and Personality" in Social Theory and Social Structure, Glencoe: The Free Press, 151-160.

Morris, V.C. (1981). Deaning: Middle Management in Academe, Urbana: University of Illinois Press.

Murray, R.K. (1964). "On Departmental Development: A Theory," Journal of General Education 16(3):227-36.

Smelser, N.J. \& Content, R. (1980). The Changing Academic Market: General Trends and a Berkeley Case Study, Berkeley: University of California Press.

Tucker, A. (1981). Chairing the Academic Department: Leadership Among Peers, Washington, D.C.: American Council on Education.

Watson, R.E.L. (1979), "The Role of the Department Head or Chairman: Discipline, Sex and Nationality as Factors Influencing Faculty Opinion," The Canadian Journal of Higher Education IX(3): 19-28.

Whitson, L.J. \& Hubert, F.W.R. (1982). "Interest Groups and the Department Chairperson: The Exertion of Influence in the Large Public University," Journal of Higher Education 53(2):163-76. 